\title{
Concomitant / Incidental Occurrence of Herpes Zoster / Shingles in Non- Insulin Dependent Diabetes Mellitus (Type 2)/ Adult Onset Diabetes Mellitus in an Elderly
}

\author{
Virendra N Sehgal* \\ Dermato-Venereology (Skin/VD) Center, Sehgal Nursing Home, India
}

Submission: November 17, 2018; Published: February 05, 2019

*Corresponding author: Virendra N Sehgal, Dermato Venerology (Skin/VD) Centre Sehgal Nursing Home, A/6 Panchwati, Delhi-110 033, India

Abstract

A rare association of herpes zoster/shingles concomitantly occurring in a heavy weight elderly man with established non-insulin dependent (Type 2)/ adult onset diabetes mellitus is reported, highlighting the cardinal clinic features apparent has numbness, tingling, painful, group of vesicle / blister over an erythematous background occupying the left cheek ipsilaterally conforming to the distribution of branches of the facial nerve. The relevant citations were taken cognizance of and incorporated in the text. The response to acyclovir $800 \mathrm{mg} 5$ times in a day for period of 10 ten days was gratifying.

Keywords: Herpes zoster; Shingles; Non-insulin dependent; Adult onset; Diabetes Mellitus

\section{Introduction}

Diabetes mellitus (DM), diabetes emerging as one of major public health problems, well-recognized all the world over [1]. It is a group of metabolic disorders, characterized by high blood sugar levels over a period of time, manifesting either as insulindependent (Type 1) or non-insulin dependent diabetes mellitus (Type 2) diabetes mellitus. Its association with wide variety of dermatoses has been subject of walk the talk time and again emphasizing its changing scenario [2,3] besides, the recalcitrant dermatoses may prompt the unfolding of diabetic state to facilitate their appropriate management [2] the current report is an update, because it provides a narrative of herpes zoster / shingles, which has been of infrequent occurrence in DM [4].

\section{Case-Report}

A 68-Year-old-elderly man, weighing 95 killograms had presented with red, swollen and blisters ridden left side of face including the chin, cheek and extending to evolve pinna of the ear. The episode had its spontaneous onset on Dec 8, 2016. The initial symptoms were numbness, tingling and pain, heralded by the appearance of the preceding redness and blistering 24 to 48 hours after till he reported for checkup. While interrogating, the patient was found to be an established incumbent of noninsulin dependent diabetes mellitus/ adult onset diabetes on metformin, the glucophage therapy, in the dosages of $1000 \mathrm{mg}$ each with the morning and evening meal.

\section{Investigations}

Blood sugar level evaluation: fasting blood sugar: $300.0 \mathrm{mg} /$ $\mathrm{dl}$ (60-100); post-parandial: $400.0 \mathrm{mg} / \mathrm{dl}$ (80-140) hemoglobin A1c (HbA1c) test, glycated hemoglobin: 12 in the beginning, at the time of It reporting, current being 8 (Good Control= 5.5-6.8 \%HbA1C, Fair Control= 6.8-8.2 \% HbA1C, Poor Control $=>8.2 \%$ HbA1C)

\section{Lipid profile}

Serum Cholesterol: $140.0 \mathrm{mg} / \mathrm{dl}$ (Desirable <200) (Borderline High 200-239)

(High Chol.> 240); HDL Cholesterol: $38.0 \mathrm{mg} / \mathrm{dl}$ (30-70); LDL Cholesterol:71.6 mg/dl (110-140); VLDL Cholesterol:30.4 MG/dl (0-40); Serum Triglycerides:152.0 mg/dl (65-170)

\section{Kidney function test}

Blood Urea: 38.0 mg/dl (15-40); Serum Creatinine: $1.5 \mathrm{mg} /$ dl (0.5-1.5); Serum Uric acid: $4.6 \mathrm{mg} / \mathrm{dl}$ (2-7); Serum Calcium: $8.9 \mathrm{mg} / \mathrm{dl}$ (8.4-11.2); Serum Sodium (Na): $141.0 \mathrm{meq} / \mathrm{L}$ (135155); Serum Potassium (K): 4.47 meq/L (3.5-5.5); Total Protein: $7.0 \mathrm{gm} / \mathrm{dl}$ (6.0-8.0); Albumin: $4.7 \mathrm{gm} / \mathrm{dl}$ (3.7-5.3)

HIV 1 \& 2 P 24 Combo test: Index value: 0.07, Non-Reactive

Herpes Simplex Virus (HSV) 1 IgM, Serum 0.28 Bio. Ref. Interval $<0.80$ 


\section{Current Research in Diabetes \& Obesity Journal}

\section{VZV immunoglobulin M (IgM) 5: Not detected}

Skin surface examination was conspicuous as erythema, edema and swellings, studded with several vesicle and /or blisters. The vesicles and blisters were largely disposed in groups. These lesions were ipsi-unilateral in their distribution confined to the left side of the face, occupying the lips, chin, cheek extending to cover pinna of the ear largely covering the areas supplied by branches of the facial nerve namely; temporal, zygomatic, buccal, marginal mandicular, and cervical branch (Figure $1 \& 2$ ).
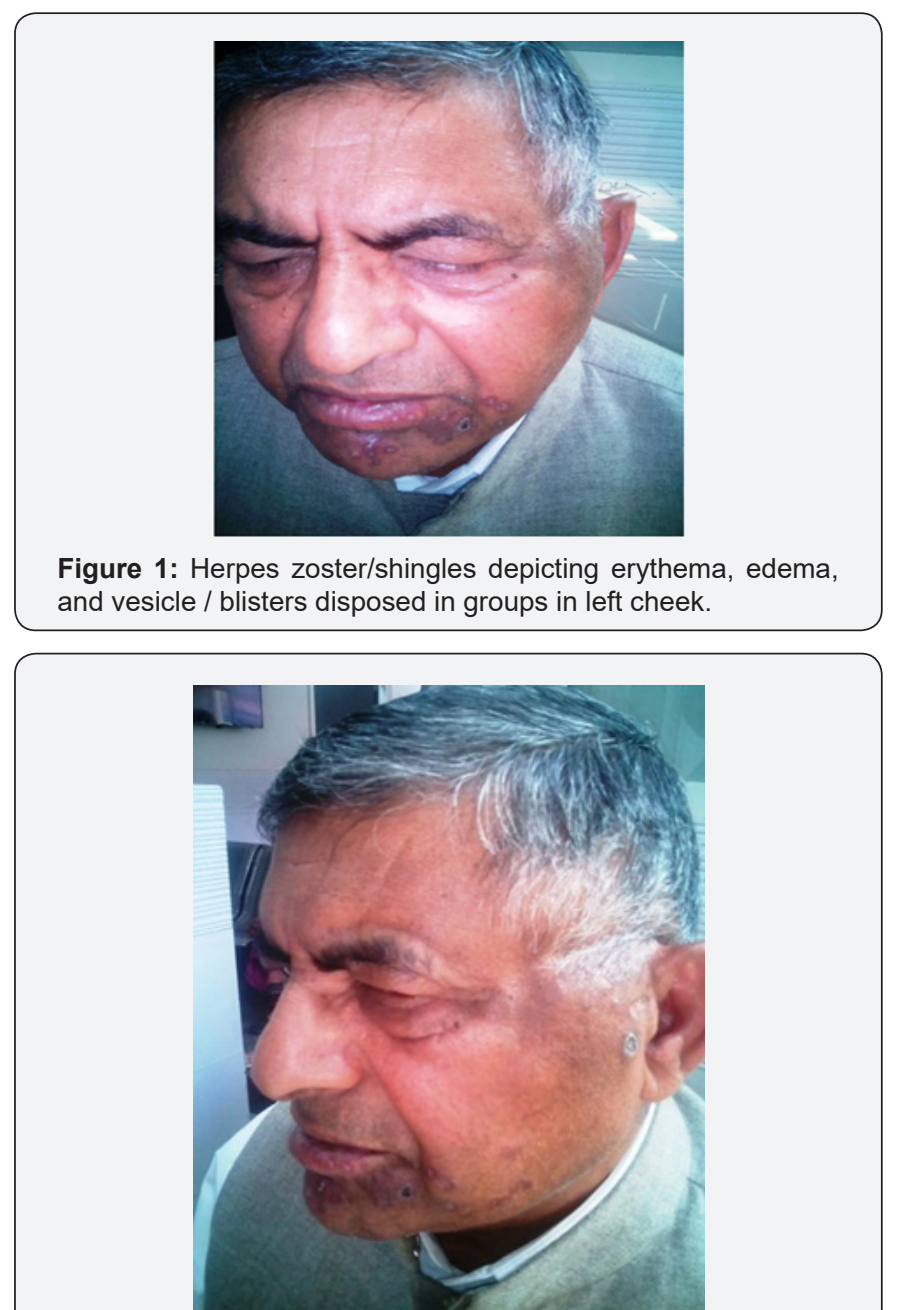

Figure 2: Herpes zoster/shingles depicting erythema, edema, and vesicle / blisters disposed in groups in left cheek.

\section{Treatment}

Acyclovir 800 miligrams (mg) was administered five (5) times daily for 10 days, with complete regression of lesions leaving behind pigmented macules.

\section{Discussion}

Indeed, the association of herpes zoster or shingles is intriguingly rare and has sparingly been reported [5-10]. It is, therefore, worthwhile at this point in time, to recall the salient features including symptoms and signs of herpes zoster / shingles. Varicella-zoster virus (VZV) human herpes virus is its incriminating cause, which usually occurs once in a person's life as chickenpox and may recur many years later as shingles $[11,12]$.

Herpes Zoster / Shingles Symptoms and signs are identified by rashes on the body; Vesicles / Blisters; Chickenpox symptoms make their appearance 7-21 days after contracting VZV for the $I^{\text {st }}$ time; painful, irritating and / or itchy lesions. Moreover, herpes zoster / shingles symptoms usually appear years after a chickenpox infection. Fatigued, tired, generally sick or weak feeling are cardinal Herpes zoster / shingles are non-contagious whereas, chickenpox is contagious during 7-21-day period and Varicella zoster virus (VZV) immunoglobulin M antibody test: may or may not be detected [13].

Furthermore, the affliction of left side of the face confined to the facial nerve and its branches, incidentally sparing them without any damage and is required to be focused attention to, especially in immuno-competent non-insulin dependent diabetes mellitus (NIDDM) type 2 or "adult-onset diabetes $[1,14]$, primarily due to excessive weight and not enough exercise [15]. The patient under review had high blood sugar levels which were detected over a prolonged period of time [1], apparent in the form of frequent urination, increased thirst, and increased hunger. HIV infected individuals are also prone to develop VZV infection [16], requiring exclusions of HIV infection.

\section{References}

1. (2014) About diabetes. World Health Organization.

2. Sehgal VN, Srivastava G, Aggarwal AK, Gupta M, Bhattacharya SN, et al. (2011) Noninsulin-dependent, type II diabetes mellitus-related dermatoses: part I. Skinmed 9(4): 240-244.

3. Sehgal VN, Srivastava G, Aggarwal AK, Gupta M, Bhattacharya SN, et al. (2011) Noninsulin-dependent, type II diabetes mellitus-related dermatoses: part II. Skinmed 9(5): 302-308.

4. Ezejiofor OI, Onayemi O, Olasode OA, Ikem RT (2013) Patterns of dermatological disorders among diabetics. Egyptian Dermatology Online Journal 9(2): 1.

5. HO Kangro, A Ward, S Argent, RB Heath, JE Cradock-Watson, et al. (1988) Detection of specific IgM in varicella and herpes zoster by antibody-capture radioimmunoassay. Epidemiol Infect 101(1): 187-195.

6. Okamoto S, Hata A, Sadaoka K, Yamanishi K, Mori Y (2009) Comparison of varicella-zoster virus-specific immunity of patients with diabetes mellitus and healthy individuals. J Infect Dis 200(10): 1606-1610.

7. Hata A, Kuniyoshi M, Ohkusa Y (2011) Risk of herpes zoster in patients with underlying diseases: a retrospective hospital-based cohort study. Infection 39(6): 537-544.

8. Yoon KJ, Kim SH, Lee EH, Choi JH (2013) Disseminated herpes zoster in an immunocompetent elderly patient. Korean J Pain 26(2): 195-198.

9. Aldaz P, Díaz JA, Loayssa JR, Dronda MJ, Oscáriz M, et al. (2013) Herpes zoster incidence in diabetic patients. An Sist Sanit Navar 36(1): 57-62.

10. Ivan Chernev, Eric Gomez (2014) Herpes Zoster and Diabetes Mellitus. Korean J Pain 27(1): 92.

11. (2014) Shingles (Herpes Zoster) Signs \& Symptoms. 


\section{Current Research in Diabetes \& Obesity Journal}

12. Furuta Y, Ohtani F, Mesuda Y, Fukuda S, Inuyama Y (2000) Early diagnosis of zoster sine herpete and antiviral therapy for the treatment of facial palsy. Neurology 55(5): 708-710.

13. Min SW, Kim YS, Nahm FS, Yoo DH, Choi E, et al. (2016) The positive duration of varicella zoster immunoglobulin $\mathrm{M}$ antibody test in herpes zoster. Medicine (Baltimore) 95(33): e4616.
14. (2013) Diabetes Fact sheet N³12". WHO.

15. Waterman G, Epstein JD, Fenske NA (1989) Herpes zoster infection with trigeminal and facial nerve involvement. Cutis 43(3): 262-263.

16. Sehgal VN, Kumart S, Jain S, Bhattacharya SN (2000) Typical varicella zoster (ophthalmicus) in an HIV-infected person. J Eur Acad Dermatol Venereol 14(1): 59-60.

\begin{tabular}{|l|}
\hline \multicolumn{1}{|c|}{ Your next submission with Juniper Publishers } \\
will reach you the below assets \\
- Quality Editorial service \\
- Swift Peer Review \\
- Reprints availability \\
- E-prints Service \\
- Manuscript Podcast for convenient understanding \\
- Global attainment for your research \\
- Manuscript accessibility in different formats \\
( Pdf, E-pub, Full Text, Audio) \\
- Unceasing customer service \\
Track the below URL for one-step submission \\
https://juniperpublishers.com/online-submission.php
\end{tabular}

